\title{
1. Transitions in socio-technical systems and challenges of city leadership
}

\section{Marina van Geenhuizen, J. Adam Holbrook and Mozhdeh Taheri}

\section{SOCIO-TECHNICAL TRANSITIONS}

The conceptualization of major increases in environmental sustainability as socio-technical transitions emerged around the turn of the century (Kemp et al. 1998; Grübler et al. 1999; Geels 2002; Ulli-Beer 2013). System thinking at the time was not new, but two key aspects in the approach were emphasized as relatively novel: first, the socio-technical nature of transitions, indicating that higher levels of sustainability can be reached only through a combination of the technical and social sides, and secondly, the multi-level character of transitions, including stability derived from rules that reproduce existing system characteristics (regime) with forces of change 'residing' in other layers among others the niche level (Geels 2002, 2010, 2011; Kemp et al. 1998).

Taking the energy sector as an example, socio-technical systems can be seen as collections of interacting physical elements, such as power plants, distribution grids, technology firms and metering systems, and social elements, including individuals, firms, governments, institutions, regulation, standards and pricing regimes. All these elements together with their linkages constitute the socio-technical system. Socio-technical systems evolve as a result of interactions among many relevant actors, while a single actor can only partially influence its own path (Geels 2002; Schot and Geels 2008). Consequently, bringing about changes that go beyond incremental steps, transitions, implicates the involvement of large numbers of actors - on the technical and social sides - along with their networks and interconnections, which is a highly comprehensive and complex endeavour. Such a situation holds true, for example, for electricity producers and suppliers, research institutes and manufacturing companies of solar panels, wind turbines, bio-mass installations, manufacturers of electric cars and 
batteries, governments in setting legal issues and providing subsidies, and for regulators of new product standards and prices (Yliskylä-Peuralahti 2016).

The applied transition literature most often addresses the energy system (and climate change) (e.g. Geels 2014), but the connected transport system has also been studied (Geels 2012; Geels et al. 2012). Accordingly, theoretical refinement of transition thinking has mainly taken place with regard to these systems. More recently, attention is also being paid to the healthcare system, in particular to the transitional change needed in view of the ageing population, urban health challenges and affordability of healthcare (World Health Organization (WHO) 2014, 2016; Bugge et al. 2015; Siri 2016). Accordingly, research is focusing on the different actors in this system, and to boundary-spanning between them, in order to have innovations brought to market more rapidly and contribute to systems change (Lander 2016; Miller and French 2016; Thune and Mina 2016). Healthcare systems, however, are undergoing relatively pronounced fragmentation - due to involvement of a large number of different actors - while testing and approval procedures of new medicines and specific medical equipment may take a relatively long time after proof-of-principle, even up to 15 years (Guldemond and van Geenhuizen 2012). The main actors here are universities (medical faculties, biology, electro-technical), (academic) hospitals, other care providers, the big pharmaceutical companies and the medical technology industry, small ventures in the same areas, testing and approval institutes, insurance companies, patients and patient organizations, and governments, which increasingly include lower level governments.

Drivers of transitions are thought to reside in one of the system levels. The multi-level perspective offers a conceptual framework for understanding the comprehensiveness and multi-dimensional complexity of socialtechnical system transitions (Smith et al. 2010; Geels 2010, 2011). Three levels are distinguished: the so-called regime, landscape and niche. Basically all these levels are non-spatial (Figure 1.1). The deep structure that accounts for stability in the socio-technical system is the socio-technical regime, and this refers to sets of rules that direct and coordinate social and economic groups that reproduce the various elements and activities of the socio-technical system. Socio-technical systems are stabilized by lock-in mechanisms, sunk cost impacts and vested interests of stakeholders causing resistance to change (Geels 2010, 2011). Next, the concept of landscape (which is also non-spatial as mentioned above) is important for understanding the broader conditions and environmental and 'external' pressures in transition. Accordingly, the landscape operates at the macro-level of political cultures, economic growth, macro-economic and technology trends, etc., and applies to pressures on the existing socio-technical regime, thereby 


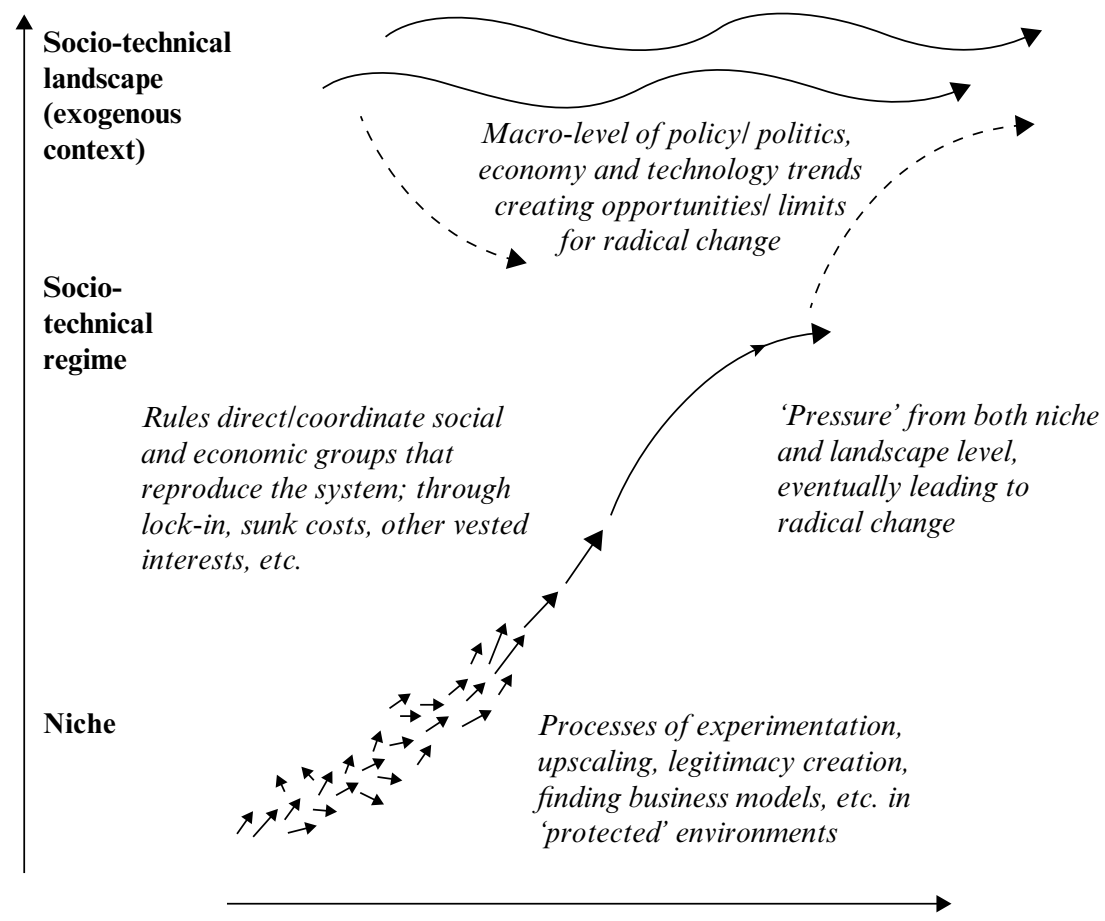

Source: Adapted from Geels (2011).

Figure 1.1 A simplified multi-level model of socio-technical transitions

creating a broader context of opportunities in an overall situation of constraints to radical changes. The Paris Agreement on climate change can be seen as an example of a force at the landscape level that aims to change the regime. However, it can be difficult for radically new policies or technologies to break through existing regimes because regulations, infrastructures, user preferences and practices, maintenance networks and business models are all aligned to the existing technology (Geels 2002).

Finally, at the lowest level of the system are the niches. Here, novel projects are nurtured in order to arrive at sufficient upscaling, for example, in experimentation in a real-life situation and subsidized demonstration projects. Niche projects are often well organized and supported in a 'protected space' for learning and experimentation, but they also often face barriers to 'mainstream' adoption. Niches are outside the constraining influence of regular market forces and competition, which is critical for developing and accomplishing transition pathways (Geels and Raven 2006; Smith and 
Raven 2012; Quitzau et al. 2012; Dóci et al. 2015). In addition, by producing convincing learning results in niches, new and disruptive technology may gain legitimacy through recognition by the main actors, such as large firms, financial institutions, governments, etc., thereby enabling further rounds of testing or upscaling of the innovation (Aldrich and Baker 2001; Markard et al. 2016). Transition pathways, however, are also propelled by pressures shaped by government, eventually along with technology trends, leading to a variety of transition pathways (Smith et al. 2010; Turnheim et al. 2015).

At the niche level, we may also find learning and experimentation projects that are less consciously driven by attempts to disrupt the established order, but serve to produce sustainability solutions that are more closely adjusted to market demand, for example, use of living labs as an innovation methodology (Almirall et al. 2012; Nyström et al. 2014; van Geenhuizen 2018). In the broader sense, living labs refer to open innovation networks. The main goal of living labs, as an innovation methodology, is to achieve better solutions for users (consumers) by co-creating new products or services with them. Living labs have been applied not only in all the three sustainability domains addressed in this volume (energy, transport and healthcare) but also in entire parts of cities (urban living labs) and universities (university or on-campus living labs). In finding ways towards sustainability transitions, increased emphasis is also being put on efficiency of measures/policies, exemplified by radically new ways of financing, like in social welfare and healthcare: rather than the intervention (or treatment), what is paid for is their positive impact (pay-for-success contracts). Social welfare is already making use of the so-called social impact bonds, while health impact bonds (HIBs), although still in the experimentation stage have been tried in a previous form (Clay 2013; Arena et al. 2015).

Remarkably, in studies on transitions towards higher sustainability, the influence of space (place) has received scarce or no attention at all for a long time. Rather, transition studies have focused on the national innovation system (e.g. Coenen et al. 2012; Truffer and Coenen 2012; Truffer et al. 2015). Consequently, the following influences have been overlooked or taken for granted. There are, first, locally embedded assets (conditions) that enhance or hamper radical sustainability inventions or policies at a particular spatial scale (e.g. city, province). Secondly, there are influences of multi-scalarity on innovation and diffusion patterns, for example collaborating local and global networks, and, thirdly, there are spatially different governance and power structures and relations, among others, allowing for or preventing more or less active roles of city governments in supporting local communities that 'attack' the regime level with grassroots innovation (e.g. Bulkeley and Betsill 2005; Avelino and Rotmans 2009; Hodson and Marvin 2009, 2010; Hatzl et al. 2016). 
Many arguments can be made to uncover the hidden urban/regional influences on socio-technical transition processes. Important here is the need for better understanding of the 'natural' diversity in physical, socioeconomic and governance endowment of places, including the potential of local places to interact with the global and produce (governance) relations enhancing the rise of drivers of transitions, or conversely, prevent any further development (e.g. Ambos et al. 2006; Coenen et al. 2012; van Doren et al. 2016; Fenton 2017). Such understanding opens ways to a better steering of the transition processes that are desired. In particular, the local level of cities/regions seems to be a well-suited environment for part of the learning/experimentation and creative design - whether it is technology creation from research and development (R\&D) or grass-roots innovation - all taking place on the basis of localized face-to-face interaction and a shared urban aim and culture. Importantly, problems of sustainability are concentrated in cities. As a consequence, an increasing number of researchers, therefore, are investigating the role of cities (city-networks) as change agents by themselves and as places where bottom-up solutions that respond to the interests of local communities emerge, however, most of these solutions still needs to be up-scaled (e.g. Evans et al. 2015, 2016; Loorbach et al. 2016; Raven et al. 2017).

This book takes a slightly different perspective, namely, one that addresses the challenges for cities in accelerating steps towards sustainability transitions, for example, by developing (ambitions for) radical change, pushing further the upper limits of technology, or enabling advanced bottom-up approaches and niche development. Such steps not only involve transformation within the city itself, it also involves a larger importance of the system(s) concerned and the city acting as a technology leader, as an example (demonstration), as a learning partner for other cities, or as an institutional inventor, thereby 'changing the rules of the game' and so on. Cities and city governments may take on different roles, active and passive ones, and some cities become leaders.

\section{AN EMERGING RESEARCH FIELD}

Urban/regionally oriented studies on transitions are rapidly increasing in number today (e.g. Bulkeley et al. 2010; Holbrook et al. 2010; McCauley and Stephens 2012; Quitzau et al. 2012; Brachert et al. 2013; Klitkou and Coenen 2013; Hansen and Coenen 2015; Truffer et al. 2015; MuñozErickson et al. 2016; Rosenbloom et al. 2016; Tanner 2016; van der Schoor et al. 2016; Wolfram and Frantzeskaki 2016; Lutz et al. 2017). It is worth noting that this literature encompasses the entire range of invention 
creation and R\&D to commercialization, mass-manufacturing and adoption (diffusion) in the market. This is also the range of the subjects covered in this book. An important point is that specific qualities of regions/cities make a difference to the potential for inventions to be created, up-scaled, introduced to market and (mass)-manufactured, and innovations to be adopted and diffused. Such differences will be emphasized in this book.

The urban/regional qualities involved are highly diverse, encompassing localized assets that are given, as inherited from nature, for instance favourable climate conditions for sun or wind energy, or localized assets that have grown in past decades, for instance city size and density (agglomeration), and patterns of infrastructure. Agglomeration assets may include: specialized research/testing sites at universities, such as medical-nuclear research facilities and 'wind-tunnels'; a testing market with launching customers; a broad range of specialized services firms; and presence of multinationals connecting the city globally (van Geenhuizen and Nijkamp 2012). Also, more active governance may be undertaken, including a wider diversity, and this broadens the study of transitions and the city for example with investigating combinations of national/local subsidies to enhance local manufacturing of innovative products, application of transformative forms of local spatial planning and selective smart city development (Batty 2013), and support of local civic society activities.

The previous examples illustrate the urban/regional influences affecting progress in transitions as presented in the book (Table 1.1) as: localized assets that are inherited from the past and in which current city policy plays no active role; localized assets that are being shaped by active policy making, eventually in interaction with bottom-up approaches, with localized institutional innovation as a specific case, as a consequence but also as an influence; and the multi-level character of the influences, such as in knowledge networks (Coenen et al. 2012; Bridge et al. 2013; Truffer et al. 2015). Also, the chapters of the book adopt different theoretical approaches to urban/regional influences providing insight into sustainability invention and adoption: agglomeration and cluster theories, relational geography approach; entrepreneurship and entrepreneurial ecosystem perspective; institutional/governance approach, and evolutionary thinking. However, most chapters include a combination of approaches (see Table 1.1).

Agglomeration and cluster theories are considered because these provide insight into local favourable conditions, for example as large cities' seedbeds benefiting from physical proximity and concomitant knowledge spillovers (Jaffe et al. 1993; Acs et al. 1994; Audretsch and Feldman 1996; Anselin et al. 1997; Duranton and Puga 2003; Capello 2009; Karlsson 2010) that may be shaping influences of the 'landscape' level (creation of a wave of new technology) and also the 'niche' level in terms of social experiments and 


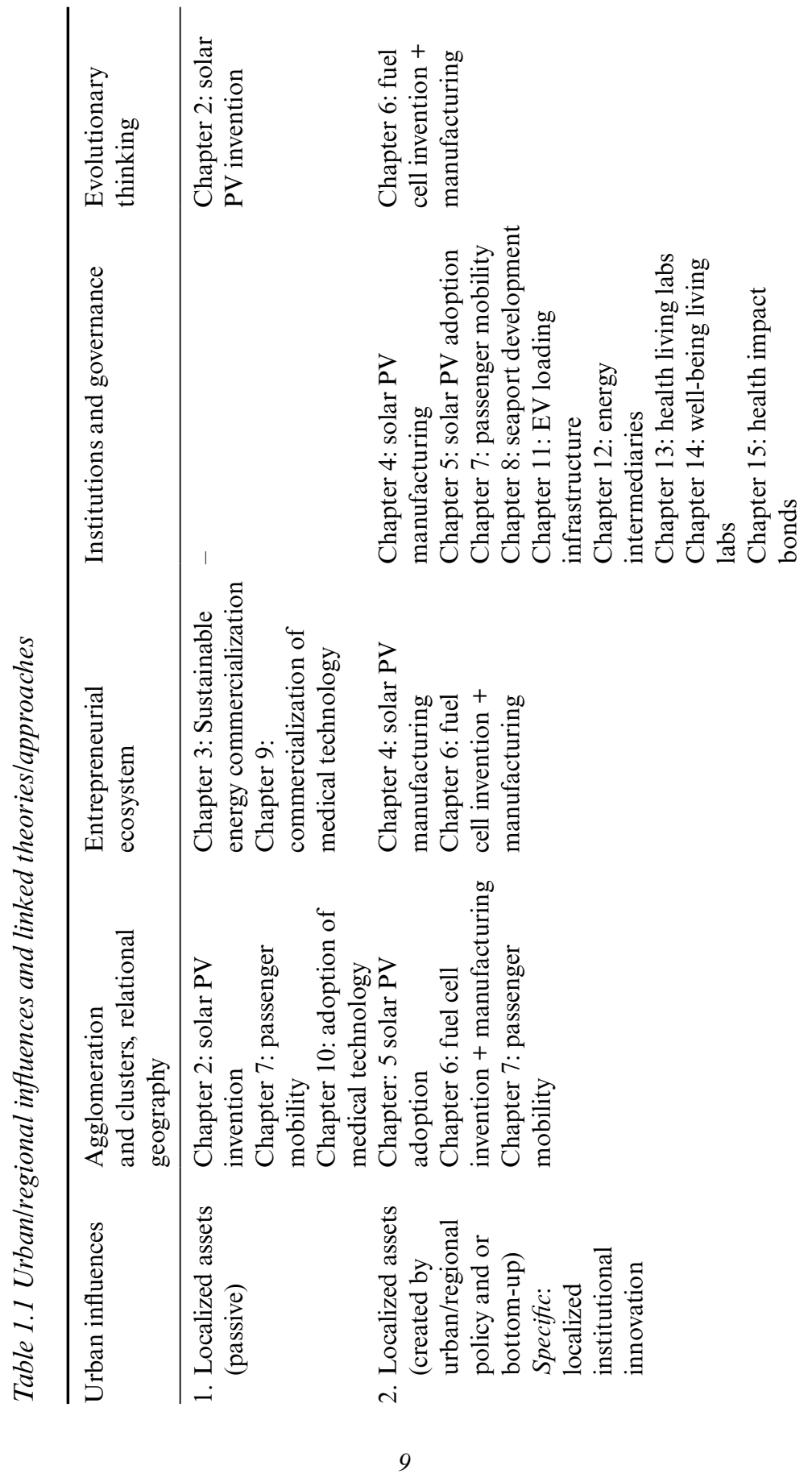




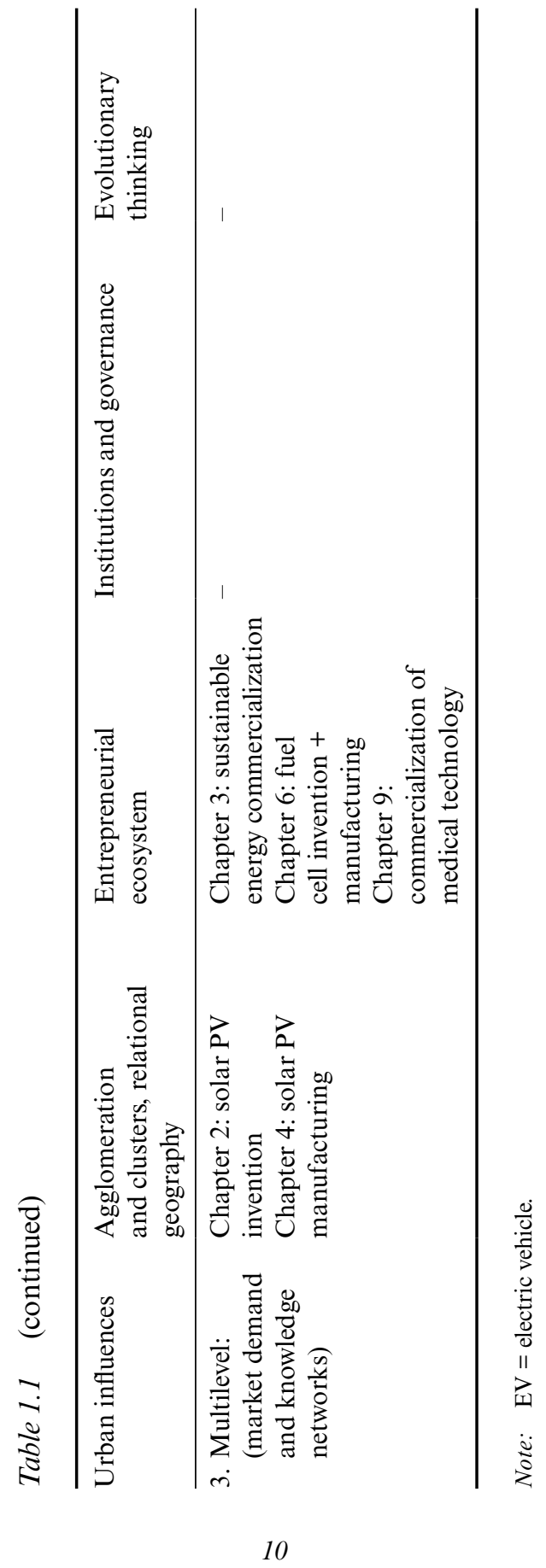


grassroots innovation. Large cities are often home to different kinds of university (general, applied, technical, specialist institutes) and research labs of large companies, where new knowledge is created and, eventually, brought to the marketplace. Increasingly, universities have adopted a broader task: engaging with societies and cities through application of research findings (Etzkowitz and Leydesdorff 1998; Etzkowitz 2008; Breznitz and Feldman 2012; Goddard and Valance 2013; Ranga and Etzkowitz 2013; Trencher et al. 2013, 2014a,b). In addition, large cities themselves may be beneficial to adoption of new technologies due to their sheer size and density as a market, as indicated in the chapters on public transport and healthcare. The previous viewpoints are most clearly adopted in Chapter 2 on photovoltaic (PV) inventions, Chapter 7 on innovation in passenger mobility and Chapter 10 on adoption of eHealth technology.

The cluster approach to sustainable (energy) technology has been adopted by many scholars in recent years, for example Holbrook et al. (2010), Madsen and Andersen (2010), and Klitkou and Coenen (2013); the same holds for regional innovation systems (e.g. Cooke 2010). As a more nuanced approach to spatial proximity and collaboration, in general, the so-called 'relational geography' has been proposed, in which it is argued that 'advantages of spatial proximity' also work at a distance, thereby emphasizing the benefits of global knowledge collaboration in technology creation (Breschi and Lissoni 2001; Ponds et al. 2007; Maggioni and Uberti 2009; Ertur and Koch 2011; Castellani et al. 2013; D'Este et al. 2013; Audretsch et al. 2014). For a relational perspective in literature, including views on the multi-scalar character of collaboration, see, for example, Binz and Truffer (2011). In the book, cluster approaches and relational theory are used in a pronounced way in Chapter 2 on PV invention, Chapter 5 on adoption of solar PV in Germany, and Chapter 6 on fuel cell invention and manufacturing.

Inventions are brought to market through different routes, among others, university patents may be licensed to large firms and university knowledge may be further developed by their 'offspring', the spin-off firms. Also, and increasingly, customer groups are involved in co-development or co-creation, thereby speeding up the time to market (Prahalad and Ramaswamy 2004). An approach that has more recently attracted attention is that of entrepreneurial ecosystems (Stam 2015, 2017; Stam and Spigel 2016). Though there are similarities with approaches such as 'regional innovation systems' and 'learning regions', the focus in entrepreneurial ecosystems is on innovative and risk-taking entrepreneurship in grasping opportunities of value creation. The approach, which is a system approach, makes a distinction between two interacting layers of framework conditions and systemic conditions, the latter including networks, leadership, finance, talent, 
knowledge, and support services and intermediaries. Entrepreneurship and value creation are seen as outcome (output) and at the same time as input into the system. Some entrepreneurs are highly innovative and forward-looking in such a way that they help introduce new technologies, for instance fuel cells, and open ways to transitional change, while other entrepreneurs may take small steps in reaching their innovation aims (e.g. Aldrich and Fiol 1994; Hervas-Olivier and Albors-Garrigos 2009; Alkemade et al. 2011; van Geenhuizen and Ye 2014; van der Vooren and Hanemaaijer 2015; Pacheco et al. 2017). The entrepreneurial ecosystem approach is adopted in Chapters 3 and 9 on the level of university spin-off firms attempting to reach the marketplace with energy and medical technology inventions, as well as in Chapter 4 on PV manufacturing firms in China.

Next, (related) institutional and governance approaches are important. In general, institutional approaches provide a lens to examine survival and legitimacy of new organizational practices, including influences from culture, regulation (legal framework), tradition, as well as (economic) incentives and resources (DiMaggio and Powell 1991; Aldrich and Baker, 2001; Baumol et al. 2009). For example, these approaches help elucidate how organizations secure their positions and legitimacy by conforming to rules and norms (North 1990; Scott 2007). Many urban/regional studies in the sustainability transition literature can be grouped under these approaches, such as those on national and local systems of economic incentives and governance, and studies on support for niche experiments, living labs and special intermediaries (Smith and Raven 2012; Klitkou and Godoe 2013; Goodrich et al. 2013; Nevens et al. 2013; Li and Yi 2014; Rohrachter and Späth 2014; Chen 2015; Martin and Coenen 2015; Sengers and Raven 2015; Affolderbach and Schultz 2016; Voytenko et al. 2016).

In this book, an institutional approach sheds light on national and local institutions and governance beneficial to the creation and adoption of new technologies. Many chapters in the book adopt an institutional approach, for instance, Chapter 4 on solar PV manufacturing in China, Chapter 5 on solar PV adoption in Germany, and Chapter 7 on passenger mobility innovation. More specifically, the following chapters deal with (new) institutional arrangements: Chapter 11 on electric vehicle (EV) loading infrastructure, Chapters 13 and 14 on living labs in various cities across the world, and, in particular in Lahti, Finland, respectively, and Chapter 15 on health impact bonds as novel financial arrangement based on the pay-for-performance principle.

A special perspective is one on actors that perform as change agents of the dominant institutional arrangements, so-called institutional entrepreneurs. These include powerful individuals and organizations, for instance city governments, which have an interest in particular institutional 
arrangements and develop activities to create new institutions or adjust existing ones by institutionalizing alternative practices, rules and logics (Battilana et al. 2009; Lawrence et al. 2011; Bulkeley et al. 2016; Fudge et al. 2016; Kukk et al. 2016). Such important actors may emerge and while creating new or adapting existing dominant institutional arrangements, they may support transitional change. Institutional entrepreneurship is considered in Chapter 4 on PV manufacturing in Chinese cities and Chapter 8 on future transition of the Rotterdam seaport. In general, transitional change is associated with manifold uncertainties and so is the policy concerned. Due to a dynamic multi-actor situation, technological uncertainty and market volatility, policy making processes and policies on sustainability and transitional change need to respond in one way or another to uncertain cause-and-effect relations and an uncertain future (Enserink et al. 2010). One specific way of dealing with multiple uncertainties is to adopt a form of flexible or adaptive policy making (van Geenhuizen and Thissen 2002; Haasnoot et al. 2013; Kasprzyk et al. 2013; Kwakkel et al. 2015). For example, the question whether once-selected policy measures (intervention) will lead to the expected results, and if they do not, whether these measures need to be adapted, is highly relevant. This issue is addressed in Chapter 11, at the city level with regard to implementation of charging infrastructure for EVs.

Finally, evolutionary approaches are relevant for understanding changes in socio-technical systems. Generally, important notions are decreasing returns, path-dependence and lock-in, new path creation, selection environments for new technologies, and co-evolution of technology and institutional change (e.g. Garud and Karnøe 2011; Simmie 2012; Brachert et al. 2013; Nykvist and Nilsson 2015). Cities and regions (clusters) show large differences in opportunities due to their specific past developments, for instance, in physical infrastructure, city morphology, economic specialization and experience with 'disasters' or other shocks. The presence of determined agents (change agents or pioneers) in new path creation in sustainability technology and in shaping new institutional arrangements is increasingly attracting research attention (e.g. Dewald and Truffer 2011; Simmie et al. 2014; Muñoz-Erickson et al. 2016). Evolutionary approaches may be applied both to sectoral (technology system) development, and cluster and regional development that is connected to particular technology (Martin 2010; Suire and Vicente 2014; Boschma 2015; Trippl et al. 2015). Both have been applied in the book, in Chapter 2 on shifts in global patterns in PV invention and Chapter 5 on growth and decline of the fuel cell cluster of Vancouver. 


\section{STRUCTURE OF THE BOOK}

This book investigates the roles that city-regions or their actors have adopted, in particular the leadership challenges in emerging transitions towards higher levels of sustainability. The book breaks new ground in the analysis of topical issues such as local seedbed conditions, public incentive schemes, niche development, living labs, impact bonds, grassroots intermediation and adaptive policy making. There is broad coverage of city-regions across the chapters, with a particular focus on Scandinavian countries such as Denmark and Finland, and Germany, the Netherlands, China and Canada. Two studies include global coverage of places of inventions and adoption of energy technology and passenger transport technology.

Following this introductory Part I, the book is organized into two more parts. Part II places emphasis on invention, commercialization and adoption, and Part III emphasizes policy making and governance. Part II includes nine empirical studies in which different categories of urban/ regional influence, particularly active urban policy, are investigated in certain segments of the energy, transport and healthcare systems. For example, the chapters cover clusters of inventions in PV technology (solar cells and panels) and emergence of their mass-manufacturing, as well as invention and mass-manufacturing in fuel cell technology. Also, in healthcare, commercialization of inventions in medical technology by university spin-off firms is investigated, alongside adoption of specific medical technology, namely, eHealth in hospitals.

Part III is devoted to governance and policy approaches in socio-technical systems. Some studies deal with new institutional arrangements and others with institutional entrepreneurship. Attention is given, for example, to the new innovation methodology of living labs and to new organizations acting as bottom-up intermediaries or platforms in cities. In addition, adaptive policy making is considered within the frame of uncertainty in demand for new infrastructure. Part III closes with a chapter summarizing the factors influencing cities' sustainability contributions, including localized assets of cities. It also outlines the practical role city governments could adopt, and proposes future research directions.

\section{THE CHAPTERS}

Part II, Assets and Networks in Cities, opens with Chapter 2, in which Pieter Stek presents a study of clusters that are 'champions' in acceleration of inventions in solar PV technology. He uses a novel bibliometric method to identify clusters of PV R\&D, which is explained in the chapter. Stek 
observes that the inventive output of the PV sector, measured by patents, has increased rapidly since 2003 , with some clusters being more successful than others, although this changes with time. However, clusters at the top of the list have held their position since 2000, and most of them are in east Asia, namely Tokyo, Osaka, Seoul and Taipei. San Jose in the US is also among the top clusters, although most high-performing clusters in the US, namely, Los Angeles, New York and Boston have lost their positions somewhat. Overall there is a shift toward a larger spread of inventive performance in PV technology across the world. In order to increase understanding of the shifts in leadership, a regression model has been estimated including both agglomeration factors and relational (network) factors. Using data on about 110 clusters, all drawn from bibliometric sources, the author concludes that agglomeration factors and relational factors tend to be equally influential and also tend to reinforce each other. It seems that US cities have lost their relative position particularly due to smaller agglomeration benefits that could not be fully compensated by strong networking. Asian cities have not lost their position but have clearly lost shares, potentially caused by the relatively smaller size of their networks.

In Chapter 3, Razie Nejabat, Mozhdeh Taheri, Victor Scholten and Marina van Geenhuizen investigate the different approaches of university spin-off firms in sustainable energy to reach the market. The firms typically combine strong technology knowledge with weaker knowledge and skills in management and market/marketing and their technology solutions, for example solar PV, wind energy, biomass and hydro. Significant attention is given to the influence of institutional aspects (countries) and circumstances such as the 'valley of death' (see Chapter 3, p. 67), which may delay or prevent introduction of the invention to market. The analysis draws on a selected sample of spin-offs in northwest Europe, and applies rough-set analysis to explore the influence of various conditional factors in an entrepreneurial ecosystems approach. Accordingly, the best chance for a quick introduction to market tends to occur with a location in an 'innovation leader' country (Sweden, Denmark, Finland) and involvement in multiple networks. This is followed by a combination of practical orientation (founders) and access to substantial investment, the latter indicating a potentially damaging effect of the 'valley of death'. Remarkably, the authors find no evidence of differences between ecosystems in large metropolitan areas and those in remote or small urban places, contrary to what agglomeration advantages would suggest. Accordingly, there is no indication of positive 'seedbed' influences or of negative influences of lack of agglomeration. Rather, in 'thin' regions indications are found for compensation of such conditions through a stronger focus of the firms on networks over a distance, and eventually on 'workplace learning'. 
Chapter 4 is concerned with mass-manufacturing in the PV industry in China, and the city's role as an institutional entrepreneur. Marina van Geenhuizen and Qing Ye investigate how the tremendous growth of China's PV industry took place and they find that various Chinese cities, in interaction with national policy incentivizing of high-tech industry and global demand for sustainable energy, gained leadership by attracting and protecting entrepreneurial companies in PV manufacturing in an unprecedented way. The authors discuss the growth of the sector in China since the early 2000s and illustrate this with two cases of PV manufacturing companies, Suntech Power and Yingli Green, in the cities of Wuxi and Baoding, respectively, along with the specific local enhancing policies. In particular, the city of Wuxi is seen as an institutional innovator, with regard to the recruitment policy of Chinese talent from overseas, as well as a refined system of local, provincial and national policy interaction in financial incentivizing of (large) domestic companies. Today, China can be considered as having (taken) the lead in acceleration of adoption of solar energy in Europe and the US, as it hosts 70 per cent of global production of solar cells/panels (2015 data). Accordingly, Chinese cities had a huge role in bringing cheap solar cells to the global market, thereby contributing to socio-technical transition in energy. However, since about 2012, the industry in China has been restructuring, with the aim to increase product quality and improve efficiency. For the foreseeable future, it is noteworthy that quality improvement in the cells (higher conversion efficiency) is mainly being achieved by US and Japanese manufacturers, and these developments make the future continuation of the role of China and its cities somewhat questionable.

In Chapter 5, Martina Fromhold-Eisebith and Ulrich Dewald develop a new, spatially relevant context, thereby focusing on socio-technical niches of PV technology, while investigating in the main the adoption side of PV technology. They propose some principles for their new approach by comparing urban and rural conditions using Germany - the country with the highest installed PV capacity in the world - as a case study. In their mainly institutional approach, while distinguishing between different PV technology market segments, the authors avoid bias in the analysis in favour of urban areas, as is present in many sustainability transition studies. While emphasizing various urban and regional assets, for example topographical nature, building and settlement features, economic structure, socio-economic entrepreneurship and policy agency, they conclude that both types of area may enhance PV technology adoption, albeit in different ways and segments. For example, thinly populated rural areas can act as large-scale centralized 'greenfield' installations on farmland. In this segment, major actors like project developers and investors are spatially 
disconnected. Conversely, in the segment of civic corporate solar systems, emerged as cooperatives, small-scale opportunities are provided for shareholder funding and local use of solar energy, and local-regional integration is much stronger. A third segment, the small-scale roof-mounted systems, with home-owners and local installers as main actors involved, is found in both rural areas and medium-sized cities, as well as fringe areas of larger cities.

Chapter 6 bridges energy systems and transport systems. It encompasses notions of agglomeration and relational economies as well as institutional aspects and city policies, thereby containing elements of all three system levels, regime, landscapes and niches. Claudia Díaz-Peréz, Brian Wixted and Adam Holbrook adopt an evolutionary approach by analysing the Vancouver fuel cell cluster, going back to the early 1980s, when not only important national R\&D programs were launched but also pioneering firms in fuel cell technology acted as technology change agents: Ballard and Angstrom. The cluster in Vancouver developed a leadership position due to favourable circumstances, particularly living conditions in the city, and importance attached worldwide to fuel cell technology and hydrogen, including substantial support from the central government of Canada. Also, the cluster was stimulated by initiatives in other regions, in particular, manufacturers that provided considerable funding for the cluster, for example, Daimler AG and Ford Motor Company. In the course of time, however, two conditions weakened growth in the cluster that was still in the pre-commercialization stage: upcoming competition from battery-electrical vehicles and hybrid vehicles, and the weaknesses of fuel cell technology appearing in the large pilot of fuel cell busses (Olympic Winter Games held at Whistler, British Columbia, Canada) namely lack of fuelling infrastructure. Once support by the national government dwindled, this pre-commercial cluster seemed not to be able to grow independently and reach maturity. Thus, in the case of Vancouver's fuel cell technology, the attractiveness of local conditions could not overcome basic competition between and among technologies. However, while the cluster is shrinking, car manufacturer Daimler is still investing and releases prototype vehicles, and new initiatives building on the existence of leading edge technology are undertaken in the cluster.

In Chapter 7, Hans Jeekel provides a broad view of innovation in passenger transport with the aim to clarify the conditions under which cities can play a leading role in creating or adopting innovations. He selects three directions, liveability, intelligent systems management and new mobility, and 16 innovations representing these directions. For each innovation, a narrative is presented as derived from experience with innovation projects and a review of the literature. The analysis results in a matrix in which the 
outcomes are summarized. The most important initiators in urban passenger mobility innovations appear to be city governments, citizen groups, public transport authorities and universities, with the enterprise world somewhat lagging behind. Furthermore, on the physical side, spatial scale tends to be important: larger cities create more innovations in mobility, but density also plays a role as high densities provide the possibility to present feasible public transport alternatives to car dominance. Importantly, the availability of one or more universities is helpful in generating inventions, as is the availability of a historic city centre that needs to be preserved against car dominance. On the social side, a population that is young, well educated and wants to continue living in the city enhances the creation of innovations in mobility; however, in some developing countries (Global South) an electorate with a majority that does not own cars, is important for innovations in public transport. Also, proactive city governments acting on open information exchange and trust, and active political leaders and citizenry with networks in leading circles, tend to be helpful. Early adopting cities mostly have experienced a crisis in mobility or failing projects, and have an open and outward looking attitude.

In Chapter 8, Marina van Geenhuizen, Lili Song and Wim Ravesteijn shift the perspective to seaport development and port cities and how these cities may move from 'business as usual' to playing a leadership role in sustainability energy transition, as technology innovator and institutional entrepreneur. The authors develop a preliminary framework of conditions that enable a seaport authority to move from 'making the port more sustainable' to a seaport that supports and accelerates comprehensive shifts in energy use, as seems increasingly the case for Rotterdam in the Netherlands. In the vision of Rotterdam, such an aim does not contradict economic development or employment growth. Rather, growth is partially created through (niche) pilot projects and experimentation with new, low carbon dioxide $\left(\mathrm{CO}_{2}\right)$, energy production and use, eventually novel logistics, and their manifold spin-off effects. The most crucial factor in realizing the new aim appears to be support from the national government, in formulating rigorous reduction of levels of $\mathrm{CO}_{2}$ production and emission. In the next part of the chapter, the authors shift attention to Chinese seaports, with the question as to how the most advanced of them, Shanghai, is performing in sustainability. The situation of Shanghai is different from that of Rotterdam, in that the former continues to emphasize economic growth as business as usual, however, stringent measures have been taken to increase sustainability in port activities. These measures are discussed and the dilemma is explained.

Next, the focus of the book shifts to empirical studies in sustainable healthcare and adopts the perspective of young entrepreneurial firms 
attempting to introduce new medical technology to market and of hospital organizations adopting such technology, in particular eHealth solutions. In Chapter 9, Mozhdeh Taheri and Marina van Geenhuizen investigate the extent to which university spin-off firms are able to reach the market with new medical technology, for example, support devices in care services (residential homes for elderly people), devices for minimally invasive surgery, technology for producing new organs, and information and communications technology (ICT) support for methods of diagnosis. The study draws on a small, selected sample and employs rough-set analysis to identify causal patterns. One of the strongest influences on introduction to market is the subsector in which the firms operate, indicating diverse technical complexity and regulation, for example, using bio-nanotechnology leads to longer time to market compared with software solutions. Furthermore, by applying in-depth case study analysis, the authors draw the preliminary conclusion that spin-offs in complex and risk-taking fields are able to survive in close research collaboration with the 'mother' university and/or academic hospital, and through this link, with universities and hospitals abroad. Spin-offs that lack such relationships tend to be much more vulnerable, particularly due to public budget constraints and firm-specific lack of management experience.

In Chapter 10, Sander Faber and Marina van Geenhuizen take the side of hospitals in their investigation of adoption of medical technology: eHealth solutions. In doing so, the authors connect with the 'landscape' level through (inter)national health policies and improving ICT. They posit that better understanding of factors influencing eHealth adoption is required given the low level of actual adoption in many European countries. Accordingly, they develop and explore a model of organizational eHealth adoption, and this is empirically tested using a survey among hospitals in different cities in the Netherlands. Specific attention is paid to adoption of new technology as a process that includes different stages; this reveals a high level of interest in eHealth (about 60 per cent of hospitals) but very limited actual adoption (ranging from 6 per cent to 23 per cent). Furthermore, the authors observe that adoption levels are relatively high in large cities. This outcome is confirmed by the model estimation (Structural Equation Modelling) indicating a significant direct influence of urban size on eHealth adoption. Other main influencing factors tend to be organizational readiness and top management of the hospitals, but these are not affected by urban size. The results of the study leave the question unanswered as to what makes hospitals in large cities more often adopt new technology if this is not mediated by hospital size and other organizational characteristics of hospitals, and - from a policy point of view - how hospitals in relatively small cities can learn from hospitals in large cities. 
The six chapters in Part III, Governance and Policy Approaches, address various leadership challenges in city governance. The focus of analysis is on adaptive policy making, institutional innovation and new arrangements. In Chapter 11, Freek Kuipéri, Marina van Geenhuizen and Jan Anne Annema investigate various uncertainties in designing a charging infrastructure for electric vehicles (EVs) in cities and provide important ingredients for adaptive policy making concerned. EVs are currently seen as one of the solutions in transport to reduce local emissions and avoid fossil fuel use. However, municipalities 'struggle' with manifold uncertainties in implementation of a charging infrastructure for EVs: future EV demand, nationally and locally; new/improved technology concerning batteries, charging equipment and alternative fuels such as hydrogen; and, integrating EV batteries as storage in renewable energy systems. In the chapter, the uncertainties are illustrated with different outcomes of scenario analysis and demand for charging infrastructure per city quarter. Further, indications are found for a slight trend of large cities being more ambitious than smaller ones in EV policy, but there may be differences between large cities, as observed for Stockholm and Amsterdam. The chapter closes with discussing policy options within an adaptive policy making framework, given the different types of uncertainty. Three options are discussed in more detail, namely, one in response to change in national policies impacting on purchasing of $\mathrm{EVs}$, one in response to the challenges in integrating EVs in larger systems of renewable energy generation, storage and use, and one in response to uncertainty in arrangements concerning exploitation of charging stations.

In Chapter 12, Marloes Dignum introduces a new type of urban intermediary, urban platform intermediaries (UPIs), and investigates their roles, actions and organizational structure in stimulating the growth of renewable energy initiatives. Urban areas are places of high transition potential due to large human inventive capital, and in this context UPIs act as strategic intermediaries that take a normative stance towards realizing sustainability aims. In the chapter, departing from insights gained from transition studies, a reflective framework is developed for UPIs to facilitate and evaluate the strategies towards provision of renewable energy. Empirically, the chapter takes a closer look at the roles and actions of two contrasting examples of UPIs in the Amsterdam Metropolitan Region, NewNRG and its spin-off 'We're getting chickens' (WGC), and Amsterdam Smart City (ASC) and its project City-Zen. Amsterdam is highly ambitious in reaching sustainable energy aims, which is further complicated by the need for degasification of its housing stock. Against this background, the two UPIs studied employ markedly different strategies. WGC is a bottom-up movement and attracts mostly newcomers (grassroots actors), while ASC started with incumbent actors and 'snowballs' from there. WGC perceives the energy transition 
as taking off and it positions itself accordingly, however, it is difficult for them to attract sufficient funding for organizational stability. By contrast, ASC has the financial means to grow but it is unlikely that it is involved in more radical activities. Despite these differences, synergy may be created between the two UPIs by sharing the aim of facilitating local change in neighbourhoods.

In Chapter 13, Marina van Geenhuizen and Nick Guldemond take a look at a way in which sustainable inventions can be quicker brought to market: living labs. The authors investigate living labs as a methodology of user-centric innovation in small-scale real-life environments, such as a living house or hospital, and pay specific attention to the relation of innovation with establishing of regional networks. The focus of the chapter is on healthcare innovation, with the aim to understand critical factors in the performance of living labs, drawing on literature and results from four case studies. The cities involved are Eindhoven and Maastricht in the Netherlands, Copenhagen in Denmark and Montreal in Canada. The two most critical factors to emerge are early involvement of user groups, including sufficient feedback, and involvement of a wider network of stakeholders, whose expertise/input matches the complexity of the target innovations. If business goals are prominent, an appropriate selection mechanism of promising inventions, including transparent go/no-go decisions, is also important, as well as the capacity of living labs' management to support writing successful research proposals in gaining financial investment. Furthermore, a trend was noted that living labs perform better if embedded in a policy with other supporting practices at local level, for instance communities of practice. An additional analysis of network building in knowledge collaboration within and outside the cluster found a trend for both local and global networking, with emphasis on the latter. These findings point to a leadership challenge that local governments may grasp, namely that of a 'connector' between the different organizations involved in living labs, between different living labs, and between living labs and other experiments in the urban/regional area, all supporting sustainability transitions.

In Chapter 14, Suvi Konsti-Laakso, Satu Pekkarinen and Helinä Melkas investigate living labs perceived as open networks through which new innovations can be developed. Their study deals with innovation in the public sector, not explicitly discussed before in this book. It examines the application of the living lab approach to enhance renewal of public wellbeing services for citizens in a regional context. Public sector innovation is often social in nature and focuses on non-technological innovations, such as a service, process or an organizational innovation. A multiple case study design is used to analyse the outcomes of 14 living lab initiatives in 
Lahti (Finland). Four different outcome categories are identified for living lab activities: access, windows, new solutions and new capabilities. This study deepens understandings of outcomes that can accrue specifically for utilizers, and therefore provides new insights and tools for researchers and practitioners. Furthermore, it contributes to the growing body of living lab research and improves the understanding of regional living lab activities and key conditions for their success. Regional living labs enhancing public sector health services can be seen as an institutional innovation.

Next, in Chapter 15, Stephan Diek, Marina van Geenhuizen and Bart van Hulst discuss a new financial arrangement, also in healthcare services: health impact bonds (HIBs). An important part of transition in healthcare is to make healthcare services more affordable but also more efficient. To this purpose, HIBs are being developed as these focus on the performance or output side of these services (pay-for-success contract). First, the authors describe the urgency of a transition in healthcare systems, in particular the need for approaches towards preventive care. Next, attention moves to the current situation of difficulties and challenges met in preventive actions on both the system level (healthcare) and the level of projects. Against this backdrop, HIBs are introduced as a relatively novel financial arrangement and it is explored to what extent HIBs can improve particular problematic situations, such as the one in which benefits of preventive care investment do not (fully) accrue to the investor. Accordingly, a preliminary list of conditions and requirements is designed to which HIBs need to be aligned. Overall, the authors expect that HIBs potentially provide substantial solutions by combining new contract forms of paying for success in performance and a shared savings contract (avoiding the 'wrong pocket' issue). The first HIB in the Netherlands, in the city of The Hague, has recently started and might enable answering remaining questions concerning the involvement of investors. The chapter closes with a summary and reflection on how cities may be involved in HIBs, including a broader perspective on healthcare transition.

In Chapter 16, Marina van Geenhuizen and Adam Holbrook summarize the main findings of the previous chapters in a city context and identify different challenges in leadership roles of cities in enhancing sustainability transitions. Accordingly, they discuss challenges in responding to favourable localized assets that are inherited, from nature or from past developments, and challenges of active city policies that connect and enhance cluster formation/strengthening and bottom-up initiatives. Specific attention is given to the key condition of attracting and retaining talent, in other words a highly skilled and diverse workforce. The chapter is closed with a discussion of factors that will enhance city leadership in the future and a presentation of important directions of future research. 


\section{A FINAL WORD}

The technologies and industries described in this book are in a state of flux, the most part, for the better. The technologies reported on have already changed beyond our greatest expectations - for example, the cost of PV panels has plummeted and battery (electrical storage) capacities have increased ten-fold while costs have dramatically decreased (The Economist 2017; see also Chapters 4 and 11 in this volume). In that sense, we have taken a snapshot, in the knowledge that we are commenting, of what is but a fleeting moment in our technological history. These changes are being driven by increased social awareness of the need to develop renewable and sustainable energy resources, and to apply these resources to a new paradigm for sustainable living in sustainable cities. The need for these changes is widely accepted by nations of every political persuasion, and for the most part the world is moving to embrace these new industries. The Paris accord on climate change has been accepted by most nations who perceive that there are both social benefits to be had, and economic advantages to be gained, by adopting these new technologies.

However, as this introduction is being written, one major industrialized nation is backing away from the Paris accords and the sciences they are built on. The editors remain confident that the rest of the world will not accept what is increasingly perceived to be a contrary opinion and that there will not be significant changes to the environment for future generations as the result of it. We live on a planet with finite resources, and we must develop and use these resources cooperatively.

\section{REFERENCES}

Acs, Z.J., Audretsch, D.B. and M.P. Feldman (1994), 'R\&D spillovers and innovative activity,' Managerial and Decision Economics, 15 (2), 131-8.

Affolderbach, J. and C. Schultz (2016), 'Mobile transitions: exploring synergies for urban sustainability research', Urban Studies, 53 (9), 1942-57.

Aldrich, H. and T. Baker (2001), 'Learning and legitimacy: entrepreneurial responses to constraints on the emergence of new populations', in C.B. Schoonhoven and E. Romanelli (eds) The Entrepreneurship Dynamic: Origins of Entrepreneurship and the Evolution of Industries (pp. 207-35), Palo Alto, CA: Stanford University Press.

Aldrich, H.E. and C.M. Fiol (1994), 'Fools rush in? The institutional context of industry creation', Academy of Management Review, 19 (4), 645-70.

Alkemade, F., Negro, S., Thompson, N. and M. Hekkert (2011), 'Towards a micro-level explanation of sustainability transitions: entrepreneurial strategies', Innovation Studies Utrecht (ISU), Working Paper Series 11, Utrecht: University of Utrecht.

Almirall, E., Lee, M. and J. Wareham (2012), 'Mapping living labs in the landscape 
of innovation methodologies', Technology Innovation Management Review, September, 1-7.

Ambos, T.C., Ambos, B. and B.B. Schlegelmilch (2006), 'Learning from foreign subsidiaries: an empirical investigation of headquarters' benefits from reverse knowledge transfers', International Business Review, 15 (3), 294-312.

Anselin, L., Varga, A. and Z. Acs (1997), 'Local geographic spillovers between university research and high technology innovations', Journal of Urban Economics, 42 (3), 422-48.

Arena, M., Bengo, I., Calderini, M. and V. Chiodo (2015), 'Social impact bonds: new finance or new procurement?', Oxford Journal of Finance and Risk Perspectives, 4 (4), 168-89.

Audretsch, D.B. and M.P. Feldman (1996), 'R\&D spillovers and the geography of innovation and production', American Economic Review, 86 (3), 630-40.

Audretsch, D.B., Lehmann, E.E. and M. Wright (2014), 'Technology transfer in a global economy', Journal of Technology Transfer, 39 (3), 301-12.

Avelino, F. and J. Rotmans (2009), 'Power in transition: an interdisciplinary framework to study power in relation to structural change', European Journal of Social Theory, 12 (4), 543-69.

Battilana, J., Leca, B. and E. Boxenbaum (2009), 'How actors change institutions: towards a theory of institutional entrepreneurship', Academy of Management Annals, 3 (1), 65-107.

Batty, M. (2013), 'Smart cities, big data', Environment and Planning B: Planning and Design, 39, 191-3.

Baumol, W.J., Litan, R.E. and C.J. Schramm (2009), Good Capitalism, Bad Capitalism, and the Economics of Growth and Prosperity, New Haven, CT: Yale University Press.

Binz, C. and B. Truffer (2011), 'Technological innovation systems in multiscalar space: Analyzing an emerging water recycling industry with social network analysis', Geographica Helvetica, 66 (4), 254-60.

Boschma, R. (2015), 'Towards an evolutionary perspective on regional resilience', Regional Studies, 49 (5), 733-51.

Brachert, M., Hornych, C. and P. Franz (2013), 'Regions as selection environments? The emergence of the solar industry in Germany from 1992-2008', European Planning Studies, 21 (11), 1820-37.

Breschi, S. and F. Lissoni (2001), 'Knowledge spillovers and local innovation systems: a critical survey', Industrial and Corporate Change, 10 (4), 975-1005.

Breznitz, S.M. and M.P. Feldman (2012), 'The engaged university', Journal of Technology Transfer, 37 (2), 139-57.

Bridge, G., Bouzarovski, S., Bradshaw, M. and N. Eyre (2013), 'Geographies of energy transition: space, place and the low-carbon economy', Energy Policy, 53, 331-40.

Bugge, M.M., Coenen, L. and A. Bransted (2015), The Roles of Governance in Co-Evolutionary and Transformative Change - The Case of Active Ageing, Lund: Centre for Innovation, Research and Competence in the Learning Economy (CIRCLE), Lund University.

Bulkeley, H. and M. Betsill (2005), 'Rethinking sustainable cities: multilevel governance and the urban politics of climate change', Environmental Politics, 14 (1) 42-63.

Bulkeley, H., Broto, V.C., Hodson, M. and S. Marvin (eds) (2010), Cities and Low Carbon Transitions, Abingdon: Routledge. 
Bulkeley, H., Powells, G. and S. Bell (2016), 'Smart grids and constitutions of solar electricity conduct', Environment \& Planning A, 48, 7-23.

Capello, R. (2009) 'Spatial spillovers and regional growth: a cognitive approach', European Planning Studies, 17 (5), 639-58.

Castellani, D., Jimenez, A. and A. Zanfei (2013), 'How remote are R\&D labs? Distance factors and international innovative activities', Journal of International Business Studies, 44 (7), 649-75.

Chen, G. (2015), 'From mercantile strategy to domestic demand stimulation: changes in China's solar PV subsidies', Asia Pacific Business Review, 21 (1), 96-112.

Clay, R.F. (2013), 'Health Impact Bonds: will investors pay for intervention?', Environmental Health Perspectives, 121 (2), a45.

Coenen, L., Benneworth, P. and B. Truffer (2012), 'Towards a spatial perspective on sustainability transitions', Research Policy, 41, 968-79.

Cooke, P. (2010), 'Regional innovation systems: development opportunities for the "green turn", Technology Analysis and Strategic Management, 22, 831-8.

D'Este, P., Guy, F. and S. Iammarino (2013), 'Shaping the formation of university-industry research collaborations: what type of proximity does really matter?' Journal of Economic Geography, 13 (4), 537-58.

Dewald, U. and B. Truffer (2011), 'Market formation in technological innovation systems - diffusion of photovoltaic applications in Germany', Industry and Innovation, 18, 285-300.

DiMaggio, P.J. and W.W. Powell (1991), 'Introduction', in W.W. Powell and P.J. DiMaggio (eds), The New Institutionalism in Organizational Analysis (pp. 1-38), Chicago: University of Chicago Press.

Dóci, G, Vasileiadou, E. and A.C. Petersen (2015), 'Exploring the transition potential of renewable energy communities', Futures, 66, 85-95.

Duranton, G. and D. Puga (2003), Micro-Foundations of Urban Agglomeration Economies, NBER Working Paper no. 9931, Cambridge, MA: NBER.

Enserink, B., Hermans, L., Kwakkel, J., Thissen, W., Koppejan, J. and P. Bots (2010), Policy Analysis of Multi-actor Systems, Utrecht: Lemma.

Ertur, C. and W. Koch (2011), 'A contribution to the theory and empirics of Schumpeterian growth with worldwide interactions', Journal of Economic Growth, 16 (3), 215-55.

Etzkowitz, H. (2008), The Triple Helix: University-Industry-Government Innovation in Action., London: Routledge.

Etzkowitz, H. and L. Leydesdorff (1998), 'The endless transition: a "Triple Helix" of university-industry-government relations', Minerva, 36, 203-8.

Evans, J., Jones, R., Karvonen, A., Millard, L. and J. Wendler (2015), 'Living labs and co-production: university campuses as platforms for sustainability science', Current Opinion in Environmental Sustainability, 16, 1-6.

Evans J., Karvonen A., and R. Raven (2016), The Experimental City, Routledge.

Fenton, P. (2017), 'The role of port cities and transnational municipal networks in efforts to reduce greenhouse gas emissions on land and at sea from shipping - an assessment of the World Ports Climate Initiative', Marine Policy, 75, 271-7.

Fudge, S., Peters, M. and B. Woodman (2016), 'Local authorities as niche actors: the case of energy governance in the UK', Environmental Innovation and Societal Transitions, 18, 1-17.

Garud, R. and P. Karnøe (2001), Path Dependence and Creation, London: Erlbaum.

Geels, F.W. (2002), 'Technological transitions as evolutionary reconfiguration processes: a multi-level perspective and a case-study', Research Policy, 31, 1257-74. 
Geels, F.W. (2010), 'Ontologies, socio-technical transition (to sustainability), and the multilevel perspective', Research Policy, 39, 495-510.

Geels, F.W. (2011), 'The multi-level perspective on sustainability transitions: response to seven criticisms', Environmental Innovation and Societal Transitions, 1, $24-40$.

Geels, F.W. (2012), 'A socio-technical analysis of low-carbon transitions: introducing the multi-level perspective into transport studies', Journal of Transport Geography, 24, 471-82.

Geels, F.W. (2014), 'Regime resistance against low-carbon transitions: introducing politics and power into the multi-level perspective', Theory, Culture \& Society, 31, 21-40.

Geels, F. and R. Raven (2006), Non-linearity and expectations in niche-development trajectories: ups and downs in Dutch biogas development (1973-2003)', Technology Analysis \& Strategic Management, 18, 375-92.

Geels, F.W., Kemp, R., Dudley, G. and G. Lyons (2012), Automobility in Transition? A Socio-Technical Analysis of Sustainable Transport, New York: Routledge.

Goddard, J. and P. Vallance (2013), The University and The City, London: Routledge.

Goodrich, A.C., Powell, D.M., James, T.L., Woodhouse, M. and T. Buonassisi (2013), 'Assessing the drivers of regional trends in solar photovoltaic manufacturing', Energy \& Environmental Science, 6, 2811-21.

Grübler, A., Nakicenovic, N. and D.G. Victor (1999), 'Dynamics of energy technologies and global change', Energy Policy, 27 (5), 247-80.

Guldemond, N. and M. van Geenhuizen (2012), "Critical factors in "livings labs" for new health concepts', CESUN Symposium, Delft, accessed 13 April 2015 at www.cesun2012.tudelft.nl.

Haasnoot, M., Kwakkel, J.H., Walker, W.E. and J. ter Maat (2013), 'Dynamic adaptive policy pathways: a method for crafting robust decisions for a deeply uncertain world', Global Environmental Change, 23, 485-98.

Hansen, T. and L. Coenen (2015), 'The geography of sustainability transitions: review, synthesis and reflections on an emergent research field', Environmental Innovation and Societal Transitions, 17, 92-109.

Hatzl, S., Seebauer, S., Flies, E. and A. Posch (2016), 'Market-based versus grassroots citizen participation initiatives in photovoltaics: a qualitative comparison of niche development', Futures 78/79, 57-70.

Hervas-Olivier, J.L. and J. Albors-Garrigos (2009), 'The role of the firm's internal and relational capabilities in clusters: when distance and embeddedness are not enough to explain innovation', Journal of Economic Geography, 9 (2), 263-83.

Hodson, M. and S. Marvin (2010), 'Can cities shape socio-technical transitions and how would we know if they are?', Research Policy 39 (4), 477-85.

Holbrook, J.A., Arthurs, D. and E. Cassidy (2010), 'Understanding the British Columbia hydrogen and fuel cells cluster', European Planning Studies, 18 (2), 317-28.

Jaffe, A.B., Trajtenberg, M. and R. Henderson (1993), 'Geographic localization of knowledge spillovers as evidenced by patent citations', Quarterly Journal of Economics, 108 (3), 577-98.

Karlsson, C. (2010), Handbook of Research on Cluster Theory, Cheltenham, UK and Northampton, MA: Edward Elgar.

Kasprzyk, J.R., Nataraj, S., Reed, P.M. and R.J. Lempert (2013), 'Many objective robust decision-making for complex environmental systems undergoing change', Environmental Modelling \& Software, 42, 55-71. 
Kemp, R., Schot, J. and R. Hoogma (1998), 'Regime shifts to sustainability through processes of niche formation: the approach of strategic niche management', Technology Analysis \& Strategic Management, 10 (2), 175-95.

Klitkou, A. and L. Coenen (2013), 'The emergence of the Norwegian solar photovoltaic industry in a regional perspective', European Planning Studies, 21 (11), 1796-819.

Klitkou, A. and H. Godoe (2013), 'The Norwegian PV manufacturing industry in a Triple Helix perspective', Energy Policy, 61 (1), 1586-94.

Kukk, P., Moors, E.H.M. and M.P. Hekkert (2016), 'Institutional power play in innovation systems: the case of Herceptin', Research Policy, 45 (8), 1493-690.

Kwakkel, J.H., Haasnoot, M. and W.E. Walker (2015), 'Developing dynamic adaptive policy pathways: a computer-assisted approach for developing adaptive strategies for a deeply uncertain world', Climatic Change, 132, 373-86.

Lander, B. (2016), 'Boundary-spanning in academic healthcare organizations', Research Policy, 45, 1524-33.

Lawrence, T., Suddaby, R. and B. Leca (2011), 'Institutional work: refocusing institutional studies of organization', Journal of Management Inquiry, 20 (1), 52-8.

Li, H. and H. Yi (2014), 'Multilevel governance and deployment of solar PV panels in U.S. cities', Energy Policy, 39 (2), 761-70.

Loorbach, D., Wittmayer, J.M., Shiroyama, H., Fujino, J. and S. Mizuguchi (eds) (2016), Governance of Urban Sustainability Transitions, European and Asian Experiences, Heidelberg/Berlin: Springer.

Lutz, L.M., Fischer, L.B., Newig, J. and D.J. Lang (2017), 'Driving factors for the regional implementation of renewable energy - a multiple case study on the German energy transition', Energy Policy, 105, 136- 47.

Madsen, A.N. and P.D. Andersen (2010), 'Innovative regions and industrial clusters in hydrogen and fuel cell technology', Energy Policy, 38 (10), 5372-81.

Maggioni, M.A. and T.E. Uberti (2009), 'Knowledge networks across Europe: which distance matters?', Annals of Regional Science, 43 (3), 691-720.

Markard, J., Wirth, S. and B. Truffer (2016), 'Institutional dynamics and technology legitimacy. A framework and a case study on biogas technology', Research Policy, $45(1), 330-44$.

Martin, R. (2010), 'Roepke Lecture in Economic Geography - rethinking regional path dependence: beyond lock-in to evolution', Economic Geography, 86, 1-27.

Martin, H. and L. Coenen (2015), 'Institutional context and cluster emergence: the biogas industry in southern Sweden', European Planning Studies, 23 (10), 2009-27.

McCauley, S.M. and J.C. Stephens (2012), 'Green energy clusters and socio-technical transitions: analysis of a sustainable energy cluster for regional economic development in Central Massachusetts, USA', Sustainability Science, 7, 213-25.

Miller, F. and M. French (2016), 'Organizing the entrepreneurial hospital: hybridizing the logics of healthcare and innovation', Research Policy, 45, 1534-1544.

Muñoz-Erickson, T.A., Campbell, L.K., et al. (2016), 'Demystifying governance and its role for transitions in urban social-ecological systems', Ecosphere, 7 (11), $1-11$.

Nevens, F., Frantzeskaki, N., Gorissen, L. and D. Loorbach (2013), 'Urban Transition Labs: co-creating transformative action for sustainable cities', Journal of Cleaner Production, 50, 111-22.

North, D.C. (1990), Institutions, Institutional Change and Economic Performance, New York: Cambridge University Press. 
Nykvist, B. and M. Nilsson (2015), 'The EV paradox - a multilevel study of why Stockholm is not a leader in electric vehicles', Environmental Innovation and Societal Transitions, 14, 26-44.

Nyström, A-G., Leminen, S., Westerlund, M. and M. Kortelainen (2014), 'Actor roles and role patterns influencing innovation in living labs', Industrial Marketing Management, 43 (3), 483-95.

Pacheco, D.A., Caten, C.S., Jung C.F., et al. (2017), 'Eco-innovation determinants in manufacturing SMEs: Systematic review and research directions', Journal of Clean Production, 142, 2277-87.

Ponds, R., van Oort, F. and K. Frenken (2007), 'The geographical and institutional proximity of research collaboration', Papers in Regional Science, 86 (3), 423-43.

Prahalad, C.K. and V. Ramaswamy (2004), 'Co-creation experiences: The next practice in value creation', Journal of Interactive Marketing, 18 (3), 6-14.

Quitzau, M., Hoffmann, B. and M. Elle (2012), 'Local niche planning and its strategic implications for implementation of energy-efficient technology', Technological Forecasting and Social Change, 79, 1049-58.

Ranga, M. and H. Etzkowitz (2013), 'Triple Helix systems: an analytical framework for innovation policy and practice in the knowledge society', Industry \& Higher Education, 27 (3), 237-62.

Raven, R., Sengers, F., Spaeth P., et al. (2017), 'Urban experimentation and institutional arrangements', European Planning Studies, published online 24 October 2017; DOI: 10.1080/09654313.2017.1393047.

Rohrachter, H. and P. Späth (2014), 'The interplay of urban policy and sociotechnical transitions: the eco-cities of Graz and Freiburg in retrospect', Urban Studies, 51, 1415-31.

Rosenbloom, D., Berton, H. and J. Meadowcroft (2016), 'Framing the sun: A discursive approach to understanding multi-dimensional interactions within socio-technical transitions through the case of solar electricity in Ontario, Canada', Research Policy, 45, 1275-90.

Schot, J. and F. Geels (2008), 'Strategic niche management and sustainable innovation journeys: theory, findings, research agenda, and policy', Technology Analysis \& Strategic Management, 20, 537-54.

Scott, W.R. (2007), Institutions and organizations: Ideas and interests, Thousand Oaks, CA: Sage Publications.

Sengers, F. and R.P.J.M. Raven (2015), 'Towards a spatial perspective on niche development', Environmental Innovation and Societal Transitions, 17, 166-82.

Simmie, J. (2012), 'Path dependence and new technological path creation in the Danish wind power industry', European Planning Studies, 20 (5), 753-72.

Simmie, J., Sternberg, R. and J. Carpenter (2014), 'New technological path creation: evidence from the British and German wind energy industries', Journal of Evolutionary Economics, 24 (4), 875-904.

Siri, J.G. (2016), 'Sustainable, healthy cities: making the most of the urban transition', Public Health Reviews, 37, 22.

Smith, A. and R. Raven (2012), 'What is protective space? Reconsidering niches in transitions to sustainability', Research Policy, 41, 1025-36.

Smith, A., Voss, J.-P., and J. Grin (2010), 'Innovation studies and sustainability transitions: the allure of the multilevel perspective and its challenges', Research Policy, 39, 435-48.

Stam, E. (2015), 'Entrepreneurial ecosystems and regional policy: a sympathetic critique', European Planning Studies, 23 (9), 1759-69. 
Stam, E. (2017), 'Measuring entrepreneurial ecosystems', USE Discussion Papers Series, Utrecht University: School of Economics.

Stam, E. and B. Spigel (2016), 'Entrepreneurial ecosystems', USE Discussion Paper Series, Utrecht University: School of Economics.

Suire, R. and J. Vicente (2014), 'Clusters for life or life cycles of clusters: in search of the critical factors of clusters' resilience', Entrepreneurship \& Regional Development, 26 (1-2), 142-64.

Tanner, A.N. (2016), 'The emergence of new technology-based industries: the case of fuel cells and its technological relatedness to regional knowledge bases', Journal of Economic Geography, 16 (3), 611-35.

The Economist (2017) 'Electrical cars are set to arrive far more speedily than anticipated', 18 February.

Thune, T. and A. Mina (2016), 'Hospitals as innovators in the health-care system: a literature review and research agenda', Research Policy, 45, 1545-57.

Trencher, G., Bai, X., Evans, J., Yarime, M. and K. McCormick (2014a), 'University partnerships for co-designing and co-producing urban sustainability', Global Environmental Change, 28, 153-65.

Trencher, G., Yarime, M., McCormick, K.B., Doll, C.N.H. and S.B. Kraines (2014b), 'Beyond the third mission: Exploring the emerging university function of co-creation for sustainability', Science and Public Policy, 41, 151-79.

Trencher, G.P., Yarime, M. and A. Kharrazi (2013), 'Co-creating sustainability: cross-sector university collaborations for driving sustainable urban transformations,' Journal of Cleaner Production, 50, 40-55.

Trippl, M., Grillitsch, M., Isaksen, A. and T. Sinozic (2015), 'Perspectives on cluster evolution. Critical review and future research issue', European Planning Studies, 23 (10), 2028-44.

Truffer, B. and L. Coenen (2012), 'Environmental innovation and sustainability transitions in regional studies', Regional Studies, 46, 1-21.

Truffer, B., Murphy J.I. and R. Raven (2015), 'The geography of sustainability transition: contours of an emerging research field', Environmental Innovation and Societal Transition, 17, 63-70.

Turnheim, B., Berkhout, F., Geels, F.W. et al. (2015), 'Evaluating sustainability transitions pathway: bridging analytical approaches to address governance challenges', Global Environmental Change, 35, 239-53.

Ulli-Beer, S. (ed.) (2013), Dynamic Governance of Energy Technology Change, Heidelberg: Springer.

van der Schoor, T., van Lente, H., Scholtens, B. and A. Peine (2016), 'Challenging obduracy: how local communities transform the energy system', Energy Research \& Social Science, 13, 94-105.

van der Vooren and A. Hanemaaijer (2015), The Valley of Death in Eco-innovation, The Hague: PBL (Environmental Assessment Agency).

van Doren, D., Driessen, P.P.J., Runhaar, H. and M. Giezen (2016), 'Scaling-up low carbon initiatives: towards a better understanding', Urban Studies 53, 175-94.

van Geenhuizen, M. (2018), 'A framework for evaluation of living labs as boundary spanners in innovation', Environment \& Planning C: Politics and Space; doi. org/10.1177/2399654417753623

van Geenhuizen, M. and P. Nijkamp (eds) (2012), Creative Knowledge Cities, Myths, Visions and Realities, Cheltenham, UK and Northampton, MA, USA: Edward Elgar. 
van Geenhuizen, M. and W. Thissen (2002), 'Uncertainty in intelligent transport systems, a policy view', Journal of Technology, Policy and Management, 2 (1), 5-19.

van Geenhuizen M. and Q. Ye (2014), 'Responsible innovators: open networks on the way to sustainability transitions', Technological Forecasting and Social Change, 87, 28-40.

Voytenko, Y., McCormick, K., Evans, J. and G. Schliwa (2016), 'Exploring urban living labs for sustainability and low carbon cities in Europe', Journal of Cleaner Production, 123, 45-54.

WHO (2014), WHO Global Forum on Innovations for Ageing Populations - Report, 12-13 December 2013, Kobe, Japan.

WHO (World Health Organization) (2016) Global Strategy and Action Plan on Ageing and Health (2016-2020) by World Health Assembly, accessed 21 March 2017 at www.who.int/ageing/global-strategy.

Wolfram, M. and N. Frantzeskaki (2016), 'Cities and systemic change for sustainability: prevailing epistemologies and an emerging research agenda', Sustainability, 8 (2), 144.

Yliskylä-Peuralahti, J. (2016), 'Sustainable energy transitions in maritime transport. The case of biofuels', Journal of Sustainable Mobility, 3 (2) 67-93. 